\title{
HUBUNGAN ANTARA KECERDASAN EMOSIONAL DENGAN PRESTASI AKADEMIK PADA MAHASISWA AKTIVIS ORGANISASI KEMAHASISWAAN DI LINGKUNGAN UNIVERSITAS UDAYANA
}

Jesica Handayanita Saragih, Tience Debora Valentina, S.Psi, M.A, Psi.

Program Studi Psikologi, Fakultas Kedokteran, Universitas Udayana

jesicahandayanitasaragih@yahoo.com

\begin{abstract}
Abstrak
Mahasiswa adalah peserta didik yang mempunyai kewajiban moral untuk menjalankan Tri Dharma Perguruan Tinggi yang mencakup tiga misi penting, yaitu menyelenggarakan pendidikan, penelitian, dan pengabdian masyarakat. Salah satu perwujudan pengabdian masyarakat yaitu mengikuti kegiatan dalam organisasi di lingkungan kampus. Mahasiswa aktivis tidak terlepas dari peran kecerdasan emosional karena mempunyai tanggungjawab yang lebih daripada mahasiswa yang tidak aktif berorganisasi. Selain menjalankan Tri Dharma Perguruan Tinggi, mahasiswa juga pasti menghadapi persoalan pribadi dan tuntutan akademik. Tujuan dari penelitian ini adalah untuk mengetahui hubungan antara kecerdasan emosional dengan prestasi akademik pada mahasiswa aktivis organisasi di lingkungan Universitas Udayana.

Teknik pengambilan sampel yang digunakan dalam penelitian ini adalah simple random sampling. Subjek dalam penelitian ini yaitu mahasiswa aktivis Universitas Udayana yang berjumlah 129 orang, usia 17-25 tahun. Peneliti menyebarkan skala kecerdasan emosional berdasarkan aspek kecerdasan emosional yang dikemukakan Goleman (2002). Selain menyebarkan skala kecerdasan emosional, peneliti juga mengumpulkan transkip nilai untuk mengetahui prestasi akademik subjek penelitian. Hubungan antara variabel kecerdasan emosional dan prestasi akademik dianalisis melalui analisis korelasi product moment Karl Pearson.

Analisis korelasi yang dilakukan pada variabel kecerdasan emosional dan prestasi akademik menghasilkan nilai koefisien korelasi sebesar -0.204 dan P sebesar 0,021 ( $\mathrm{p}<0,05)$. Hasil penelitian ini menunjukkan terdapat hubungan negatif antara kecerdasan emosional dengan prestasi akademik. Artinya adalah peningkatan kecerdasan emosional diikuti penurunan prestasi akademik pada mahasiswa aktivis organisasi kemahasiswaan. Banyaknya jumlah organisasi yang diikuti di lingkungan kampus, jumlah aktivitas yang diikuti di luar lingkungan kampus, dan faktorfaktor eksternal lain dari subjek penelitian memberikan sumbangan terhadap pengaruh prestasi akademik.
\end{abstract}

Kata kunci : kecerdasan emosional, prestasi akademik, mahasiswa aktivis organisasi.

\begin{abstract}
Student is a learner who has moral duties in applying Tri Dharma Perguruan Tinggi consisted of three important missions, which are implementing education, research, and community service. One embodinent of community service is being involved in the organizational activities around campus. Student activists have an immense relation with the role of emotional intelligence since they have more responsibilities than those who are not actively participating in organisation. In addition to running the missions of Tri Dharma Perguruan Tinggi, students would also encounter personal problem and be faced with school's demands. The purpose of conducting this research is to investigate the correlation of emotional intelligence and academic achievement of student organization activists at University of Udayana.

The sampling technique used in this research was simple random sampling. Subjects were 129 student activists at University of Udayana, age ranged from 17 to 25 years old. Emotional intelligence scale was deployed based on emotional intelligence aspects proposed by Goleman (2002). Transcripts were also collected to determine academic achievement of the subjects, aside from spreading the emotional intelligence scale. Karl Pearson product-moment correlation analysis was conducted to observe correlation of emotional intelligence and academic achievement.

Correlation coefficient value obtained from the result of analysis performed on the variables, emotional intelligence and academic achievement, were -0.204 and $\mathrm{P}$ of $0.021 \quad(\mathrm{p}<0.05)$. This result shows that there is a negative relationship between emotional intelligence and academic achievement, which also indicates that the increase of emotional intelligence is followed by the decrease of academic achievement on student organization activists. The number of organizations in which the subjects participated in, various activities performed outside campus, and other external factors of research's subjects contributed to the effect of academic achievements.
\end{abstract}

Keyword: emotional intelligence, academic achievement, student organization activists. 


\section{LATAR BELAKANG}

Mahasiswa adalah sebutan bagi individu yang telah menyelesaikan pendidikan ditingkat SD, SMP, dan SMA. Kata mahasiswa berasal dari kata maha yang berarti besar atau tinggi dan siswa adalah pelajar atau individu yang sedang menuntut ilmu. Mahasiswa adalah peserta didik yang terdaftar dan belajar pada suatu perguruan tinggi, baik di perguruan tinggi negeri maupun perguruan tinggi swasta atau lembaga lain yang setingkat dengan perguruan tinggi (Sudarman, 2004). Data dari situs resmi Direktorat Jenderal Pendidikan Tinggi Kementrian Pendidikan dan Kebudayaan Republik Indonesia, dari Aceh sampai Papua di tahun 2014 sudah tersebar 120 Perguruan Tinggi Negeri atau yang disingkat PTN dan 3.078 Perguruan Tinggi Swasta atau yang disingkat PTS, yang berbentuk universitas, sekolah tinggi, akademi, dan politeknik. Salah satu perguruan tinggi negeri di Indonesia adalah Universitas Udayana yang terdapat di Pulau Bali.

Berdasarkan data populasi yang didapat dari bagian kemahasiswaan Universitas Udayana, tercatat 22.423 orang jumlah mahasiswa yang dinyatakan aktif sebagai mahasiswa pada tahun akademik 2013-2014 di Universitas Udayana, mulai dari mahasiswa ditingkat diploma sampai tingkat Strata 3 (S3). Berdasarkan data tersebut, terdapat 17.498 orang mahasiswa yang dinyatakan aktif di tingkat Strata 1 (S1), yang berada di 46 program studi dalam 13 Fakultas.

Universitas Udayana dan universitas lain yang sejajar dengan perguruan tinggi menjalankan peraturan pemerintah mengenai tugas atau kewajiban moral dan tanggung jawab perguruan tinggi yang tertulis dalam UU No. 12 tahun 2012 pasal 1 ayat 9 tentang Pendidikan Tinggi (UU Dikti) yang mencatat mengenai Tri Dharma Perguruan Tinggi. Tri Dharma Perguruan Tinggi adalah kewajiban perguruan tinggi untuk menyelenggarakan pendidikan, penelitian, dan pengabdian masyarakat. Lubis (2004) memaparkan bahwa melalui pendidikan dalam Tri Dharma Perguruan Tinggi diharapkan mahasiswa mempunyai dasar berpikir yang benar dalam memutuskan berbagai hal di dunia kampus maupun luar kampus. Penelitian dilakukan agar mahasiswa diharapkan mampu mengaplikasikan ilmu pengetahuan yang diperoleh semasa proses pendidikan di perguruan tinggi. Pengabdian masyarakat dilakukan agar mahasiswa dapat membantu masyarakat dan mampu memenuhi kebutuhannya sendiri. Salah satu perwujudan pengabdian mahasiswa kepada masyarakat yaitu dengan mengikuti kegiatan dalam organisasi, baik organisasi di lingkungan kampus maupun organisasi di luar kampus. Hal tersebut melatar belakangi keberadaan organisasi kemahasiswaan pada setiap Perguruan Tinggi dan mendukung keaktifan mahasiswa-mahasiswa dalam organisasi kemahasiswaan yang ada.

Organisasi kemahasiswaan adalah sebuah wadah yang didukung oleh pihak kampus yang dapat memberikan kesempatan bagi mahasiswa untuk mengembangkan diri dalam berbagai aspek melalui kegiatan-kegiatan positif didalamnya. Selain sebagai perwujudan pengabdian mahasiswa kepada masyarakat, mahasiswa didorong untuk terlibat dalam organisasi kemahasiswaan karena dalam proses belajar mengajar di perkuliahan, baik di dalam kelas maupun di laboratorium, tidak semua hal dapat dipelajari sehingga mahasiswa dapat memperolehnya melalui organisasi kemahasiswaan. Aktivitas yang diikuti mahasiswa dalam organisasi kemahasiswaan dilakukan di luar jam perkuliahan yang dapat mengembangkan minat dan bakat yang dimiliki oleh mahasiswa. Organisasi kemahasiswaan di Universitas Udayana sebanyak 37 organisasi. Data tersebut diperoleh dari data bagian kemahasiswaan Univesitas Udayana.

Mahasiswa yang aktif dalam organisasi secara umum disebut sebagai mahasiswa aktivis (Mansyur, 1978). Menurut Parera (2000) kriteria mahasiswa aktivis adalah mahasiswa yang menjabat sebagai pengurus organisasi, memiliki pengalaman dan keterampilan dalam berorganisasi.

Keaktifan mahasiswa aktivis dengan berbagai kegiatan atau aktivitas dalam menjalankan tugas dan tanggung jawab di organisasi mempunyai dampak positif maupun negatif. Adapun dampak positif dari keaktifan dalam organisasi berdasarkan hasil penelitian Setyono (2013) antara lain:

a. Mudah bergaul dan mendapat banyak relasi.

b. Memiliki pengalaman yang lebih daripada mahasiswa yang tidak aktif dalam berorganisasi.

c. Memiliki sifat mandiri tidak tergantung dengan orang lain.

d. Berpikiran luas dan rasional.

e. Rasa solidaritas yang tinggi terhadap sesama mahasiswa terutama anggota yang ada di dalam organisasi yang diikuti.

Selain itu, dampak negatif dari keaktifan dalam organisasi berdasarkan hasil penelitian Setyono (2013) antara lain:

a. Mengikuti perkuliahan sering terlambat dan bahkan sering membolos demi mengikuti kegiatan organisasi yang diikuti.

b. Prestasi akademik kurang baik bahkan cenderung menurun.

c. Seringkali tidak tepat waktu dalam menyelesaikan perkuliahan.

Penelitian mengenai dampak aktif berorganisasi juga dilakukan oleh Ahmaini (2010) yang berjudul "Perbedaan Prokrastinasi Akademik Antara Mahasiswa Yang Aktif Dengan Yang Tidak Aktif Dalam Organisasi Kemahasiswaan Pema Universitas Sumatera Utara”. Hasil dari penelitian ini yaitu adanya dampak negatif dari keaktifan berorganisasi sehingga terjadi prokrastinasi akademik pada mahasiswa. Mahasiswa yang tidak aktif dalam organisasi lebih rendah prokrastinasi akademiknya dibandingkan mahasiswa yang aktif berorganisasi. Oleh karena itu, dapat disimpulkan bahwa terdapat perbedaan prokrastinasi akademik antara mahasiswa yang aktif pada organisasi dan yang tidak pada mahasiswa Universitas Sumatera Utara. 
Mulyanafi (2014) juga meneliti tentang keaktifan berorganisasi pada mahasiswa yang berjudul "Perbedaan Keterampilan Komunikasi Interpersonal Pada Mahasiswa Fakultas Ilmu Sosial dan Ilmu Politik Universitas Brawijaya Ditinjau Dari Keaktifan Berorganisasi”. Hasilnya menunjukkan bahwa terdapat dampak positif dari keaktifan mahasiswa berorganisasi yaitu adanya perbedaan keterampilan berkomunikasi antara mahasiswa yang aktif dan yang tidak aktif berorganisasi. Mahasiswa Fakultas Ilmu Sosial dan Ilmu Politik Universitas Brawijaya yang aktif berorganisasi memiliki keterampilan komunikasi interpersonal yang lebih tinggi dengan mahasiswa yang tidak aktif berorganisasi.

Hasil penelitian-penelitian lainnya mengenai mahasiswa aktivis memaparkan bahwa terlihat adanya perbedaan dan perubahan yang signifikan pada mahasiswa aktivis terhadap wawasan, cara berpikir, pengetahuan dan ilmu-ilmu sosialisasi, kepemimpinan serta menajemen kepemimpinan yang tidak diajarkan dalam kurikulum Perguruan Tinggi.

Mahasiswa aktivis dengan berbagai tugas dan tanggung jawab di dalam organisasi kemahasiswaan juga mempunyai tanggung jawab dalam dunia kampus dan akan menghadapi persolan-persoalan pribadi. Azwar (2004) memaparkan bahwa kehidupan mahasiswa di usia yang telah dianggap dewasa, tidaklah statis, melainkan selalu dinamis, akan menghadapi berbagai persoalan pribadi, biasanya diwarnai oleh tekanan, tuntutan dan tantangan, baik dalam proses belajar mengajar maupun kehidupan sehari-hari dengan dunia sekitarnya. Masalah yang mungkin dihadapi oleh mahasiswa seperti kegagalan dalam menjalani proses belajar, tidak mendapatkan nilai sesuai dengan yang diinginkan, terlalu lelah dalam menjalani rutinitas kuliah, tidak dapat membagi waktu antara belajar dengan keterlibatannya dalam organisasi mahasiswa, ataupun permasalahan pribadi lainnya seperti kehilangan seseorang yang sangat berarti, misalnya adanya perceraian orang tua, ataupun kehilangan karena orang terdekat atau kerabat terdekat meninggal dunia.

Disisi lain dari persoalan yang mungkin dihadapi seperti yang telah dipaparkan, diperkuliahan setiap mahasiswa dituntut untuk menyelesaikan Sistem Kredit Semester (SKS). Mahasiswa di Universitas Udayana wajib menempuh minimal 144 SKS dan boleh mengambil SKS lebih, yaitu maksimal 160 SKS. Batas waktu yang ditetapkan yaitu 8 sampai 14 semester, dengan standar kelulusan Indeks Prestasi Kumulatif, yang biasa disingkat IPK, minimal 2,00 dan maksimal 4,00. Indeks prestasi kumulatif di tingkat Perguruan Tinggi di Indonesia dihitung sebagai rata-rata norma nilai prestasi akademik yang diperoleh mahasiswa pada setiap mata kuliah. Prestasi akademik dipandang sebagai sesuatu yang penting untuk dicapai setiap mahasiswa. Prestasi akademik menurut Suryabrata (2006) adalah hasil belajar terakhir yang dicapai oleh peserta didik dalam jangka waktu tertentu, dimana prestasi akademik biasanya dinyatakan dalam bentuk angka atau simbol tertentu. Angka atau simbol tersebut untuk mengetahui prestasi akademik yang telah dicapai. Menurut Sobur (2006) prestasi akademik merupakan bukti dari hasil usaha yang diperoleh mahasiswa selama mengikuti perkuliahan yang dilihat melalui indeks prestasi kumulatif. Koesma (2003) menyebutkan bahwa hasil usaha tersebut merupakan penilaian proses belajar melalui kuis, tugas, UTS, dan UAS yang diberikan dari masing-masing mata kuliah yang diikuti kemudian dikuantifikasikan dalam bentuk indeks prestasi. Nilai-nilai yang diperoleh mahasiswa mempunyai ukuran standar untuk mengetahui sejauh mana tercapainya pengetahuan dan keterampilan mahasiswa dari apa yang telah diajarkan.

Selain itu prestasi akademik juga menunjukkan sejauh mana kemampuan daya serap mahasiswa dalam belajar. Prestasi akademik yang tinggi menggambarkan daya serap yang tinggi, demikian sebaliknya. Oleh karena itu, secara tidak langsung prestasi yang dicapai menjadi prediksi bagi keberhasilan individu dan cerminan individu yang berkualitas. Selain itu, prestasi akademik menjadi salah satu bekal bagi mahasiswa untuk menghadapi dunia kerja dan juga diakui oleh masyarakat semakin tinggi.

Menghadapi persoalan pribadi dan tuntutan pencapaian prestasi akademik yang baik, tidak semua mahasiswa dapat bertahan dan mengembangkan dirinya kembali. Oleh karena itu, kecerdasan emosional menjadi penting bagi mahasiswa khususnya pada mahasiswa aktivis agar mampu mengikuti kegiatan dalam organisasi yang diikutinya dan menjalankan perkuliahan dengan baik.

Kemampuan intelektual atau yang sering disebut IQ (Intelligence Quotient) memang harus diakui mempengaruhi prestasi akademik. Namun fenomena yang ada menunjukkan bahwa tidak sedikit pelajar dengan kecerdasan intelektual tinggi memiliki prestasi rendah, bahkan memiliki resiko menghadapi kegagalan akademis. Hal ini menunjukkan bahwa kecerdasan intelektual tidak selalu dapat menentukan prestasi akademik seseorang.

Menurut Ahmadi dan Supriyono (2004) faktor-faktor yang mempengaruhi prestasi akademik adalah adanya faktor internal atau faktor dari dalam diri individu dan faktor eksternal atau faktor yang berasal dari luar diri individu. Faktor internal yang mempengaruhi prestasi akademik menurut meliputi faktor fisiologis dan faktor psikologis. Faktor fisiologis yaitu kesehatan tubuh dan keberfungsian panca indera khususnya pengelihatan, pendengaran, serta kesehatan mental. Faktor psikologis yaitu faktor potensial yang meliputi intelektual dan bakat, serta faktor kecakapan nyata sehari-hari. Faktor psikologis yang meliputi unsur-unsur kepribadian tertentu seperti sikap, kebiasaan, minat, kebutuhan, motivasi, kecerdasan emosional, penyesuaian diri. 
Unsur-unsur tersebut terjadi dipengaruhi kematangan fisik maupun psikis dan lingkungan.

Faktor eksternal yang mempengaruhi individu meliputi lingkungan keluarga, lingkungan pendidikan, lingkungan masyarakat, dan lingkungan kelompok atau komunitas, dan teman.

Pemaparan di atas menyimpulkan bahwa terdapat banyak faktor yang mempengaruhi prestasi akademik, baik dari faktor internal maupun faktor eksternal, dimana salah satunya adalah kecerdasan emosional (Ahmadi dan Supriyono, 2004).

Goleman (2009) berpendapat bahwa kecermelangan seorang individu berdasarkan IQ (Intelligence Quotient) hanyalah sekitar $20 \%$, dan $80 \%$ lainnya bergantung pada faktor lain, diantaranya adalah kecerdasan emosional yang sering disebut EQ (Emotional Quotient). Goleman menemukan bahwa banyak orang yang gagal dalam hidupnya bukan karena rendahnya kecerdasan intelektualnya, tetapi dapat disebabkan karena kurang memiliki kecerdasan emosional yang baik. Menurut Goleman kecerdasan emosional sebagai serangkaian kemampuan pribadi, emosi dan sosial yang mempengaruhi kemampuan seseorang untuk berhasil dalam mengatasi tututan dan tekanan di lingkungan.

Goleman (2009) mendefinisikan kecerdasan emosional adalah kemampuan yang dimiliki individu dalam memotivasi diri, ketahanan dalam menghadapi kegagalan, mengendalikan emosi dan menunda kepuasan, serta mengatur keadaan jiwa. Selain itu, Gottman \& DeClaire (1998) juga menegaskan bahwa kecerdasan emosional bagi individu sangatlah penting.

Berdasarkan pemaparan di tersebut, peneliti tertarik untuk melakukan penelitian mengenai hubungan antara kecerdasan emosional dengan prestasi akademik pada mahasiswa aktivis organisasi kemahasiswaan di lingkungan Universitas Udayana.

\section{METODE}

\section{Variabel dan Definisi Operasional}

Adapun variabel yang digunakan dalam penelitian ini adalah sebagai berikut :

a. Variabel tergantung

Variabel tergantung adalah variabel yang dipengaruhi atau yang menjadi akibat karena adanya variabel bebas (Purwanto, 2010). Variabel tergantung dikenal dengan nama variabel dependen. Variabel tergantung dalam penelitian ini adalah prestasi akademik berdasarkan Indeks Prestasi Kumulatif atau IPK mahasiswa aktivis organisasi kemahasiswaan di lingkungan Universitas Udayana.

Prestasi akademik merupakan hasil belajar yang dicapai peserta didik selama kurun waktu pendidikan yang ditempuh mahasiswa yang diketahui melalui evaluasi belajar. Evaluasi dalam proses belajar mahasiswa di tingkat perguruan tinggi diberikan melalui kuis, tugas, UTS, dan UAS dari materi diperkuliahan dengan tujuan untuk mengetahui prestasi akademik mahasiswa (Suryabrata, 2006).

b. Variabel bebas

Variabel bebas adalah variabel yang mempengaruhi variabel tergantung (Purwanto, 2010). Variabel bebas juga dikenal dengan variabel independen. Variabel bebas yang digunakan dalam penelitian ini adalah kecerdasan emosional.

Kecerdasan emosional adalah kemampuan memahami perasaan atau emosi diri sendiri, memiliki kemampuan berempati terhadap perasaan orang lain dan memiliki kemampuan mengelola emosi sehingga individu dapat memilah-milah perasaan dan menggunakan informasi yang didapat untuk membimbing pikiran dan tindakan. Penelitian ini menggunakan aspek-aspek kecerdasan emosional yang dikemukakan Goleman (2002), yang meliputi kesadaran diri, pengelolaan emosi, motivasi diri, empati, dan keterampilan sosial.

\section{Responden dan Tempat Penelitian}

Responden atau sampel yang digunakan dalam penelitian ini diambil dalam populasi mahasiswa aktivis organisasi kemahasiswaan di lingkungan Universitas Udayana yang memiliki karakteristik sebagai berikut:

a. Mahasiswa atau mahasiswi aktivis organisasi kemahasiswaan Universitas Udayana tahun 2014 yang mempunyai pengalaman berorganisasi minimal 1 tahun.

b. Masih terdaftar sebagai mahasiswa tingkat Strata 1 di Universitas Udayana tahun 2014.

c. Terdaftar sebagai mahasiswa Universitas Udayana sejak tahun angkatan 2008 sampai tahun 2014. Artinya adalah mahasiswa yang saat ini sedang berada di semester 3 sampai semester 13 .

Responden yang terpilih dan memenuhi kriteria penelitian yang digunakan sebagai data penelitian yaitu 129 orang. Jumlah sampel tersebut telah memenuhi syarat jumlah minimum menurut rumus Slovin yaitu sebanyak 89 orang.

Penelitian ini dilakukan di Universitas Udayana wilayah Denpasar dan Bukit Jimbaran, Bali karena sesuai dengan tujuan peneliti.

\section{Alat ukur dan Metode Pengumpulan Data}

Metode pengumpulan data merupakan cara yang dilakukan peneliti untuk mengumpulkan data yang akan dianalisis sehingga kemudian peneliti mendapatkan kesimpulan yang tepat dalam menjawab pertanyaan atau masalah penelitian (Purwanto, 2010). Metode pengumpulan data dalam penelitian ini dilakukan melalui penelitian 


\section{J.H. SARAGIH DAN T.D.VALENTINA}

lapangan (field work research) dan melalui metode dokumentasi.

Instrumen penelitian yang digunakan dalam penelitian lapangan (field work research) untuk mengumpulkan data melalui alat bantu pengukuran berupa kuesioner yang berisi skala kecerdasan emosional yang diberikan kepada sampel penelitian. Skala kuisoner tersebut menggunakan skala dari disertasi yang disusun oleh Rustika (2014). Skala dalam penelitian ini terdiri dari 26 aitem pernyataan. Skala disusun berdasarkan 5 paradigma atau aspek-aspek kecerdasan emosional yang dikemukakan Goleman (2002), meliputi kesadaran diri, pengelolaan emosi, motivasi diri, empati, dan keterampilan sosial.

Menurut Kartono (1990) metode dokumentasi adalah teknik pemeriksaan dokumen dengan pengumpulan informasi dan data secara langsung sebagai hasil pengumpulan sendiri oleh peneliti atau disebut juga data primer. Data yang dikumpulkan bersifat asli sehingga dapat dipergunakan secara langsung. Teknik pemeriksaan dokumen digunakan untuk melakukan pengumpulan data terhadap prestasi akademik yang menggunakan transkip nilai akademik seluruh sampel penelitian untuk melihat Indeks Prestasi Kumulatif atau IPK.

\section{Teknik Analisis Data}

Setelah mengumpulkan data yang dibutuhkan, dilakukan analisis data dengan menggunakan teknik korelasi product moment dari Karl Pearson melalui program SPSS for windows untuk mengolah data mentah kecerdasan emosional dan prestasi akademik, yang telah distandarisasi menjadi $\mathrm{T}$ Score melalui program SPSS.

Adapun langkah-langkah dalam menganalisis data dalam penelitian ini adalah sebagai berikut (Hadi, 2002):

\section{Analisis Deskriptif}

a. Mencari rata-rata atau mean dari variabel $\mathrm{X}$ dan variabel $\mathrm{Y}$

b. Mencari Varian / Skor Deviasi (SD)

c. Mencari skor tertinggi $\mathrm{X}$ dan $\mathrm{Y}$

d. Mencari skor terendah X dan Y

2. Uji Persyaratan Analisis

Sebelum dilakukan uji korelasi maka dilakukan uji persyaratan terlebih dahulu dengan menggunakan uji-uji sebagai berikut:

\section{a. Uji Normalitas}

Uji normalitas dilakukan untuk menguji apakah sampelsampel yang diambil mempunyai data yang berdistribusi normal atau tidak. Uji normalitas ini dilakukan dengan menggunakan uji One Sample Kolmogorov-Smirnov dengan bantuan program komputer SPSS for windows. Santoso (2005) memaparkan bahwa dasar pengambilan keputusan dari hasil analisis uji normalitas menandakan data yang diperoleh berdistribusi normal apabila memperoleh nilai $\mathrm{p}>0,05$. Sebaliknya apabila nilai signifikasi (nilai probabilitas) $<0,05$ maka data tidak berdistribusi normal.

\section{b. Uji Linieritas}

Uji linieritas dilakukan untuk mengetahui apakah kedua variabel yang diteliti berhubungan secara langsung atau tidak sehingga dapat memberikan gambaran perubahan pada variabel bebas akan diikuti oleh perubahan variabel tergantung dengan membentuk garis linear.

Uji linieritas dilakukan dengan menggunakan analisis statistik uji probability dengan bantuan program komputer SPSS for windows. Kaidah yang digunakan untuk mengetahui linier atau tidaknya hubungan antara variabel bebas dengan variabel tergantung adalah dengan melihat nilai probability atau Deviation from Linearity yang artinya jika $p>0,05$ maka hubungan antara variable bebas dengan variabel tergantung dinyatakan linier, sebaliknya jika $\mathrm{p}<0,05$ berarti hubungan antara variabel bebas dengan variabel tergantung dinyatakan tidak linier (Hadi, 2002). Apabila uji asumsi terpenuhi, maka dilanjutkan dengan uji hipotesis.

\section{Analisis Uji Hipotesis}

Uji hipotesis dilakukan dengan menggunakan teknik analisis korelasi product moment. Pengambilan keputusan untuk menerima atau menolak hipotesis dilakukan dengan melihat nilai signifikansi, dengan taraf signifikansi yang digunakan sebesar 5\% $(0,05)$ atau kebenaran hipotesis memiliki taraf kepercayaan sebesar 95\%. Hipotesis dikatakan memiliki hubungan yang signifikan bila nilai probilitas lebih kecil dari 0,05 ( $\mathrm{p}<0.05)$.

Penelitian ini juga mempunyai data tambahan atau data demografi. Analisis tambahan dilakukan untuk memperkaya hasil penelitian. Data tambahan pada penelitian ini meliputi jenis kelamin, usia, fakultas, serta jumlah organisasi kemahasiswaan dan jumlah kegiatan di luar lingkungan kampus yang diikuti.

\section{HASIL PENELITIAN}


1. Deskripsi Data Penelitian

\begin{tabular}{lcc} 
& $\begin{array}{c}\text { Tabel 1. } \\
\text { Profil Subjek Berdasarkan Jenis Kelamin }\end{array}$ \\
\hline \multicolumn{1}{c}{ Jenis Kelamin } & Jumlah & Persentase (\%) \\
\hline Laki-laki & 70 & $54,26 \%$ \\
Perempuan & 59 & $45,74 \%$ \\
Total & 129 & $100.0 \%$ \\
\hline
\end{tabular}

Tabel 1. menunjukkan bahwa subjek penelitian lebih didominasi berjenis kelamin laki-laki, yaitu sebesar 70 orang $(54,26 \%)$ dari 129 subjek dan sisanya berjenis kelamin perempuan, yaitu sebesar 59 orang $(45,74 \%)$.

\begin{tabular}{ccc} 
Tabel 2. \\
& Profil Subjek Berdasarkan Usia \\
\hline & Jumlah & Persentase $(\%)$ \\
\hline Usia & 99 & $76.74 \%$ \\
17-20 TAHUN & 30 & $23.26 \%$ \\
\hline 21-25 TAHUN & 129 & $100.0 \%$ \\
\hline Total & &
\end{tabular}

Berdasarkan tabel 2. di atas, diketahui bahwa subjek penelitian yang berusia 17-20 tahun sebanyak 99 orang $(76,74 \%)$ dan yang berusia 21-25 tahun sebanyak 30 orang $(23,26 \%)$. Hal tersebut menyatakan bahwa sebagian besar subjek penelitian berusia antara 17-20 tahun.

\begin{tabular}{|c|c|c|}
\hline \multicolumn{3}{|c|}{ Profil Subjek Berdasarkan Fakultas } \\
\hline Fakultas & Jumlah & Presentase $(\%)$ \\
\hline Fakultas Kedokteran & 20 & $15,5 \%$ \\
\hline $\begin{array}{l}\text { Fakultas Ilmu Sosial dan Ilmu } \\
\text { Politik }\end{array}$ & 11 & $8.5 \%$ \\
\hline Fakultas Hukum & 3 & $2.3 \%$ \\
\hline Fakultas Teknik & 15 & $11.6 \%$ \\
\hline Fakultas Ekonomi dan Bisnis & 24 & $18.6 \%$ \\
\hline Fakultas Kelautan dan Perikanan & 8 & $6,2 \%$ \\
\hline Fakultas Kedokteran Hewan & 11 & $8.5 \%$ \\
\hline $\begin{array}{l}\text { Fakultas Matematika dan Ilmu } \\
\text { Pengetahuan Alam }\end{array}$ & 7 & $5.4 \%$ \\
\hline Fakultas Sastra danBahasa & 4 & $3.1 \%$ \\
\hline Fakultas Peternakan & 4 & $3.1 \%$ \\
\hline Fakultas Pariwisata & 14 & $10.9 \%$ \\
\hline Fakultas Teknik Pertanian & 2 & $1.6 \%$ \\
\hline Fakultas Pertanian & 6 & $4.7 \%$ \\
\hline Total & 129 & $100.0 \%$ \\
\hline
\end{tabular}

Tabel 3. menunjukkan bahwa dari 129 mahasiswa yang dijadikan sebagai subjek penelitian, didominasi oleh mahasiswa dari Fakultas Ekonomi dan Bisnis (FEB) yaitu sebanyak 24 orang $(18,6 \%)$ dan yang paling sedikit berasal dari Fakultas Teknik Pertanian (FTP) yaitu sebanyak 2 orang $(1,6 \%)$.

\section{Tabel 4.}

\begin{tabular}{|c|c|c|c|}
\hline \multicolumn{4}{|c|}{ Profil Subjek Berdasarkan Pengalaman Berorganisasi } \\
\hline No & Pengalaman Mahasiswa Aktivis & Jumlah & Persentase (\%) \\
\hline 1 & $\begin{array}{l}\text { Pernah atau sedang menjabat sebagai pengurus dalam } \\
\text { organisasi. }\end{array}$ & 129 & $100 \%$ \\
\hline 2 & Ikut serta sebagai panitia dalam kegiatan organisasi. & 115 & $89,1 \%$ \\
\hline 3 & $\begin{array}{l}\text { Memiliki pengalaman presentasi suatu program } \\
\text { organisasi di luar lingkungan kampus. }\end{array}$ & 43 & $33,3 \%$ \\
\hline 4 & $\begin{array}{l}\text { Memiliki pengalaman presentasi suatu program } \\
\text { organisasi di lingkungan kampus. }\end{array}$ & 63 & $48,8 \%$ \\
\hline 5 & $\begin{array}{l}\text { Memiliki pengalaman menyusun program atau kegiatan } \\
\text { dalam organisasi. }\end{array}$ & 90 & $69,7 \%$ \\
\hline 6 & $\begin{array}{l}\text { Mampu mendorong atau menggerakkan atau mengajak } \\
\text { orang-orang di dalam maupun di luar organisasi untuk } \\
\text { menjalankan suatu program. }\end{array}$ & 78 & $60,5 \%$ \\
\hline 7 & Terlibat minimal satu tahun dalam organisasi. & 129 & $100 \%$ \\
\hline
\end{tabular}

Tabel 4. menunjukkan bahwa semua subjek dalam penelitian ini adalah pernah atau sedang menjabat sebagai pengurus dalam organisasi kemahasiswaan di lingkungan Universitas Udayana dan semua subjek dalam penelitian ini sudah terlibat dalam organisasi kemahasiswaan minimal 1 tahun. Selain itu, tabel tersebut menunjukkan bahwa terdapat $89,1 \%$ yang pernah ikut serta sebagai panitia dalam kegiatan organisasi, terdapat $33,3 \%$ yang pernah memiliki pengalaman presentasi suatu program organisasi diluar lingkungan kampus, terdapat $48,8 \%$ yang pernah memiliki pengalaman presentasi suatu program organisasi di lingkungan kampus, terdapat $69,7 \%$ yang memiliki pengalaman dalam menyusun program atau kegiatan dalam organisasi, dan terdapat $60,5 \%$ yang mengaku mampu mendorong atau menggerakkan atau mengajak orang-orang di dalam maupun di luar organisasi untuk menjalankan suatu program.

\begin{tabular}{ccc} 
Tabel 5. \\
\multicolumn{4}{c}{ Deskripsi Indeks Prestasi Kumulatif (IPK) Subjek } \\
\hline IPK & Jumlah & Persentase (\%) \\
\hline $2.00-2.75$ & 5 & $13.1 \%$ \\
$2.76-3.50$ & 75 & $60.8 \%$ \\
$3.51-4.00$ & 49 & $26.1 \%$ \\
\hline Total & 129 & $100.0 \%$ \\
\hline
\end{tabular}

Tabel 5. menunjukkan bahwa mahasiswa yang memiliki indeks prestasi kumulatif 2,00-2.75 dengan predikat memuaskan berjumlah 5 orang $(13,1 \%)$, mahasiswa yang memiliki indeks prestasi kumulatif antara 2.76-3.50 dengan predikat sangat memuaskan berjumlah 75 orang $(60,8 \%)$, dan mahasiswa yang memiliki indeks prestasi kumulatif antara 3.50-4.00 predikat dengan pujian berjumlah 49 orang $(26,1 \%)$. Hal ini menunjukkan bahwa sebagian besar subjek penelitian berada pada kategori skor prestasi akademik dengan predikat sangat memuaskan.

\begin{tabular}{|c|c|c|c|c|}
\hline \multicolumn{5}{|c|}{$\begin{array}{c}\text { Deskripsi Prestasi Akademik dengan Jumlah Organisasi di Lingkungan Kampus yang } \\
\text { Diikuti }\end{array}$} \\
\hline \multicolumn{5}{|c|}{$\begin{array}{ll}\text { JUMLAH ORGANISASI * IPK Crosstabulation } \\
\end{array}$} \\
\hline \multirow[t]{2}{*}{ JUMLAH ORGANISASI } & \multicolumn{3}{|c|}{ IPK } & \multirow[t]{2}{*}{ Total } \\
\hline & $2.00-2.75$ & $2.76-3.50$ & $3.51-4.00$ & \\
\hline 1.00 & 2 & 34 & 26 & 62 \\
\hline 2.00 & 1 & 22 & 10 & 33 \\
\hline 3.00 & 1 & 10 & 9 & 20 \\
\hline 4.00 & 1 & 3 & 1 & 5 \\
\hline 5.00 & 0 & 6 & 3 & 9 \\
\hline Total & 5 & 75 & 49 & 129 \\
\hline
\end{tabular}

Tabel 6. menunjukkan bahwa mahasiswa yang aktif di satu organisasi yang memperoleh IPK 2.00-2.75 ada sebanyak 2 orang, yang memperoleh IPK 2.76-3.50 dengan predikat sangat memuaskan, ada sebanyak 34 orang dan yang memperoleh IPK 3.51-4.00, dengan predikat dengan pujian, ada sebanyak 26 orang. Hal tersebut menunjukkan perbeda perolehan IPK yang mengikuti 2, 3, 4, dan 5 organisasi.

\begin{tabular}{|c|c|c|c|c|}
\hline \multicolumn{5}{|c|}{$\begin{array}{l}\text { Tabel } 7 . \\
\text { Deskripsi Subjek Berdasarkan Prestasi Akademik dan Aktivitas di Luar Kampus yang } \\
\text { Diikuti }\end{array}$} \\
\hline \multicolumn{5}{|c|}{ JUMLAH AKTIVITAS EKSTERNAL * IPK Crosstabulation } \\
\hline JUMLAH AKTIVITAS & & IPK & & Total \\
\hline EKSTERNAL & $2.00-2.75$ & $2.76-3.50$ & $3.51-4.00$ & \\
\hline 0.00 & 1 & 43 & 25 & 69 \\
\hline 1.00 & 4 & 22 & 16 & 42 \\
\hline 2.00 & 0 & 5 & 7 & 12 \\
\hline 3.00 & 0 & 3 & 1 & 4 \\
\hline 4.00 & 0 & 1 & 0 & 1 \\
\hline 5.00 & 0 & 1 & 0 & 1 \\
\hline Total & 5 & 75 & 49 & 129 \\
\hline
\end{tabular}


Tabel di atas menunjukkan bahwa mahasiswa yang tidak ada mengikuti aktivitas organisasi di luar kampus berjumlah 69 orang dan didominasi dengan perolehan IPK 2.76 - 3.50 yaitu ada sebanyak 43 orang dan yang memperoleh IPK 3.51 - 4.00 didominasi juga oleh subjek yang tidak mengikuti aktivitas organisasi di luar kampus, yaitu ada sebanyak 25 orang. Mahasiswa yang tidak mengikuti aktivitas organisasi di luar kampus paling banyak memperoleh IPK dengan predikat sangat memuaskan dan dengan pujian dibandingkan dengan mahasiswa yang mengikuti sebanyak 1 atau 2 atau sampai 5 aktivitas organisasi di luar kampus.

2. Analisis Deskriptif

Tabel 8.

\begin{tabular}{ccc}
\multicolumn{3}{c}{ Deskripsi Data Variabel Penelitian } \\
\hline Variabel & Kecerdasan Emosional & Prestasi Akademik \\
\hline N & 129 & 129 \\
Mean & 65 & 50 \\
SD & 13 & 10 \\
Xmin & 26 & 20 \\
Xmax & 104 & 80
\end{tabular}

Tabel di atas menunjukkan bahwa Mean Teoritis yang diperoleh dari variabel kecerdasan emosional yaitu 65 dan Mean Teoritis yang diperoleh dari variabel prestasi akademik yaitu 50 .

Tinggi rendahnya kategori subjek diketahui dengan melakukan kategorisasi pada skala kecerdasan emosional dan prestasi akademik. Kategorisasi tersebut dibedakan menjadi tiga kategori interval yaitu: tinggi, sedang, rendah. Kategori subjek penelitian dilihat melalui perhitungan secara empiris yang didasarkan pada besarnya simpangan baku ideal (SDi), skor Mean Ideal (Mi), skor tertinggi dan skor terendah deskripsi penelitian.

Penggolongan tiga kategori dalam penelitian ini didasarkan pada rumus sebagai berikut:

Tinggi : Mean + 1SD s.d Skor tertinggi

Sedang : Mean - 1 SD s.d < Mean + 1SD

Rendah : Skor terendah s.d < Mean - 1 SD

Adapun deskripsi data kecerdasan emosional dan prestasi akademik adalah sebagai berikut:

a. Deskripsi Data Kecerdasan Emosional

Kriteria ideal deskripi data kecerdasan emosional diketahui dengan menghitung skor minimum dan skor maksimum pada variabel kecerdasan emosional secara empiris. Skor tersebut menghasilkan Mean Ideal (Mi) dan Standar Deviasi ideal (SDi).

Adapun deskripsi data variabel kecerdasan emosional dapat dijelaskan sebagai berikut :

i. Tendensi sentral

Data variabel kecerdasan emosional menghasilkan skor minimum 50, skor maksimum $=102$, skor Mean $(M)=79,25$ dan skor standar Deviasi $(\mathrm{SD})=8,25$.

\section{ii. Distribusi Frekuensi}

Penggolongan variabel kecerdasan emosional dibedakan menjadi tiga bagian yaitu skor 26 sampai < 52, skor 52 sampai
$<78$, dan skor 78 sampai 104. Klasifikasi penggolongan dapat dilihat pada tabel berikut ini:

\begin{tabular}{cccc}
\multicolumn{4}{c}{ Tabel 9. } \\
& Frekuensi Data Kecerdasan Emosional & \\
\hline Skor & Jumlah & Presentase $(\%)$ & Kategori \\
\hline 26 sampai $<52$ & 1 & $0,78 \%$ & Rendah \\
52 sampai $<78$ & 60 & $46.51 \%$ & Sedang \\
78 sampai 104 & 68 & $52.71 \%$ & Tinggi \\
Total & 129 & $100 \%$ & \\
\hline
\end{tabular}

Melalui tabel di atas diketahui bahwa sebesar $52.71 \%$ subjek penelitian berada pada skor kecerdasan emosional 78104, sebesar $46.51 \%$ subjek penelitian berada pada skor kecerdasan emosional 52-77, dan sebesar 0,78\% subjek penelitian berada pada skor kecerdasan emosional 26-51. Berdasarkan hal tersebut disimpulkan bahwa mayoritas subjek penelitian berada pada kategori kecerdasan emosional tinggi.

\section{b. Deskripsi Data Prestasi Akademik}

Kriteria ideal deskripsi data prestasi akademik diketahui dengan menghitung dengan kriteria ideal melalui skor minimum dan skor maksimum yaitu 16,22-71,02 sehingga menghasilkan Mean Ideal $(\mathrm{Mi})=50,0$ dan Standar Deviasi Ideal $(\mathrm{SDi})=9,51$

Adapun deskripsi data variabel prestasi akademik dapat dijelaskan sebagai berikut:

i. Tendensi sentral

Skor prestasi akademik yang dianalisis telah diubah dari data mentah menjadi standar baku atau $\mathrm{T}$ Score dengan program SPSS sehingga menghasilkan Mean $=50$, dengan skor minimum 16,22 dan skor maksimum $=71,02$, dan skor Standar Deviasi (SD)=9,52.

ii. Distribusi Frekuensi

Penggolongan variabel prestasi akademik dibedakan menjadi tiga kategori yaitu tinggi, sedang, dan rendah. Klasifikasi penggolongan dapat dilihat pada tabel10.

\begin{tabular}{cccc}
\multicolumn{5}{c}{ Tabel 10. } \\
& Distribusi Frekuensi Data Prestasi Akademik & \\
\hline Skor & Jumlah & Presentase $(\%)$ & Kategori \\
\hline$<40$ & 16 & $12,40 \%$ & Rendah \\
$40-60$ & 96 & $74,42 \%$ & Sedang \\
$61-80$ & 17 & $13,18 \%$ & Tinggi \\
Total & 129 & $100 \%$ & \\
\hline
\end{tabular}

Berdasarkan tabel tersebut terdapat $74,42 \%$ subjek penelitian berada pada skor prestasi akademik 40-60 dengan kategori sedang, sebesar $13,18 \%$ subjek penelitian berada pada skor prestasi akademik 61-80 dengan kategori tinggi, dan sebesar $12,40 \%$ subjek penelitian berada pada skor prestasi akademik $<40$ dengan kategori rendah. Hal tersebut dapat disimpulkan bahwa mayoritas subjek penelitian memiliki prestasi akademik dengan kategori sedang, yaitu sebanyak 96 orang $(74,42 \%)$.

\section{Uji Prasyarat Analisis}

a. Uji Normalitas.

Uji normalitas dilakukan dengan menggunakan Uji Kolmogorov-Smirnov Z. Data dikatakan berdistribusi normal jika $\mathrm{p}>0,05$. 
Tabel 11.

Hasil Uji Normalitas Sebaran

One-Sample Kolmogorov-Smirnov Test ${ }_{\text {Unstandardized Residual }}$

\begin{tabular}{llr}
$\mathrm{N}$ & & 129 \\
\hline Normal Parameters ${ }^{\mathrm{a}, \mathrm{b}}$ & Mean & $0 \mathrm{E}-7$ \\
& Std. Deviation & 9.32006500 \\
& Absolute & .107 \\
Most Extreme Differences & Positive & .054 \\
& Negative & -107 \\
Kolmogorov-Smirnov Z & & 1.214 \\
Asymp. Sig. (2-tailed) & & .105 \\
Test distribution is Normal. & & \\
Calculated from data. & & \\
\hline
\end{tabular}

Hasil uji kolmogorov-smirnov $\mathrm{Z}$ yang diperoleh pada tabel 11. adalah sebesar 1,214 dengan Asymp.Sig 0,105. Hal tersebut berarti lebih besar dari 0,05 sehingga data penelitian berdisribusi secara normal.

\section{b. Uji Linieritas}

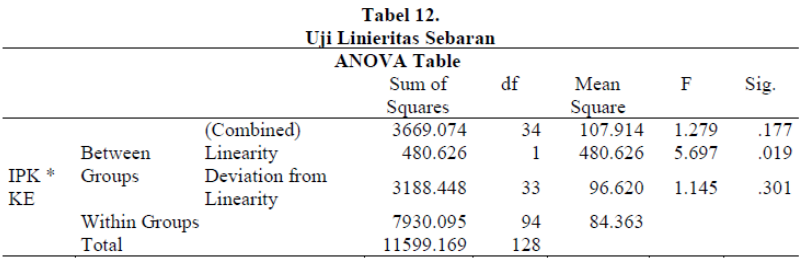

Tabel 12. menjelaskan bahwa nilai probability sebesar 0,301 yang berarti lebih besar dari 0,05 sehingga dapat dikatakan bahwa data penelitian yang diperoleh berdistribusi secara linier.

\section{c. Uji Hipotesis}

Hipotesis dikatakan memiliki hubungan yang signifikan bila nilai probilitas lebih kecil dari 0,05 ( $\mathrm{p}<0.05)$. Penjelasan mengenai korelasi pada variabel penelitian dapat dilihat pada tabel berikut ini :

\begin{tabular}{|c|c|c|c|}
\hline \multicolumn{4}{|c|}{$\begin{array}{c}\text { Tabel } 13 . \\
\text { Hasil Analisis Korelasi Product Moment } \\
\text { Correlations }\end{array}$} \\
\hline & & $\mathrm{KE}$ & IPK \\
\hline \multirow{3}{*}{$\mathrm{KE}$} & Pearson Correlation & 1 & $-204^{*}$ \\
\hline & Sig. (2-tailed) & & .021 \\
\hline & $\mathrm{N}$ & 129 & 129 \\
\hline \multirow{3}{*}{ IPK } & Pearson Correlation & $-.204^{*}$ & 1 \\
\hline & Sig. (2-tailed) & .021 & \\
\hline & $\mathrm{N}$ & 129 & 129 \\
\hline
\end{tabular}

Tabel di atas menunjukkan bahwa nilai koefisien korelasi antara variabel kecerdasan emosional dan prestasi akademik adalah -0,204. Nilai probablilitas pada taraf signifikansi $5 \%$ sebesar $0,021(\mathrm{p}=0,021)$. Artinya adalah nilai probabilitas lebih kecil dari 0,05 ( $\mathrm{p}<0,05)$, hal tersebut menunjukkan bahwa variabel $\mathrm{x}$ signifikan terhadap variabel sehingga disimpulkan ada atau terdapat hubungan atau korelasi antara kecerdasan emosional dan prestasi akademik mahasiswa aktivis organisasi kemahasiswaan di Universitas Udayana. Namun, tanda negatif pada koefisien korelasi menunjukkan bahwa terdapat korelasi negatif antara kecerdasan emosional terhadap prestasi akademik. Hal tersebut mengartikan bahwa setiap peningkatan kecerdasan emosional tidak diikuti dengan peningkatan prestasi akademik, tetapi penurunan bagi prestasi akademik, begitu juga sebaliknya bahwa peningkatan prestasi akademik tidak diikuti oleh peningkatan kecerdasan emosional.

\section{PEMBAHASAN DAN KESIMPULAN}

1. Kecerdasan Emosional Mahasiswa Aktivis Organisasi Kemahasiswaan Universitas Udayana

Hasil analisis dari penelitian ini menunjukkan bahwa mayoritas kecerdasan emosional pada mahasiswa aktivis organisasi kemahasiswaan Universitas Udayana berada pada kategori tinggi. Hal tersebut ditunjukkan dengan adanya sebanyak 68 orang subjek penelitian $(52.71 \%)$ berada pada skor kecerdasan emosional $78-104$.

Tinggi rendahnya kecerdasan emosional seseorang pada dasarnya akan berpengaruh pada sikap atau perilaku dari individu itu sendiri. Hal ini sesuai dengan penelitian Rachmawati (2013) yaitu perbedaan kecerdasan emosional menimbulkan perbedaan karakteristik pada diri individu, selain itu tinggi rendahnya kecerdasan emosional juga berpengaruh pada sikap individu terhadap lingkungan sosialnya.

Mayer dalam (Shapiro, 2003) kecerdasan emosional atau yang sering disebut EQ (Emotional Quality) adalah bagian dari kecerdasan sosial karena memiliki kemampuan memahami perasaan atau emosi orang lain dan diri sendiri dan kemampuan dalam keterampilan sosial.

Hasil penelitian ini menunjukkan bahwa mahasiswa aktivis organisasi kemahasiswaan Universitas Udayana mempunyai ciri-ciri sebagai berikut, yaitu mampu mengendalikan perasaan marah, tidak agresif dan memiliki kesabaran, memikirkan akibat sebelum bertindak, berusaha dan mempunyai daya tahan untuk mencapai tujuan hidupnya, menyadari perasaan diri sendiri dan orang lain, dapat berempati pada orang lain, dapat mengendalikan mood atau perasaan negatif, memiliki konsep diri yang positif, mudah menjalin persahabatan dengan orang lain, mahir dalam berkomunikasi, dan dapat menyelesaikan konflik sosial dengan cara damai karena individu mampu atau memiliki kesadaran diri, pengelolaan emosi, motivasi diri, empati, dan keterampilan sosial yang baik. Hal tersebut sesuai dengan pemaparan Goleman (2002).

Dampak positif dari keaktifan dalam organisasi dipaparkan Djojodibroto (2004), yaitu mudah bergaul dan mendapat banyak relasi dan memiliki rasa solidaritas yang tinggi terhadap sesama mahasiswa terutama sesama anggota yang ada di dalam organisasi yang diikuti. Hal tersebut karena individu mampu atau memiliki kesadaran diri, pengelolaan emosi, empati, dan keterampilan sosial yang baik. Selain mudah bergaul dan memiliki rasa solidaritas yang tinggi, dampak positif dari mahasiswa yang aktif dalam organisasi kemahasiswaan yaitu memiliki pengalaman yang lebih daripada mahasiswa yang tidak aktif dalam berorganisasi serta 
mampu berpikiran luas dan rasional. Pengalaman berorganisasi serta kemampuan berpikiran luas dan rasional pada mahasiswa aktivis dalam organisasis kemahasiswaan karena individu memiliki motivasi diri yang baik, yaitu adanya antusianisme untuk aktif dalam organisasi kemahasiswaan.

2. Prestasi Akademik Mahasiswa Aktivis Organisasi Kemahasiswaan Universitas Udayana

Hasil analisis dari penelitian ini menunjukkan bahwa mayoritas prestasi akademik pada mahasiswa aktivis organisasi kemahasiswaan Universitas Udayana berada pada kategori sedang. Hal tersebut ditunjukkan dengan adanya sebanyak 96 orang subjek penelitian $(74,42 \%)$ berada pada kategori skor 40-60.

Tinggi rendahnya prestasi akademik atau hasil belajar dapat dipengaruhi oleh banyak faktor. Faktor-faktor yang mempengaruhi prestasi akademik adalah adanya faktor dari dalam diri individu dan faktor yang berasal dari luar diri individu (Ahmadi dan Supriyono, 2004). Faktor-faktor dari dalam diri individu atau faktor internal meliputi faktor fisiologis yaitu kesehatan tubuh dan keberfungsian panca indera khususnya pengelihatan, pendengaran, serta kesehatan mental; faktor psikologis yaitu intelektual, bakat, unsur-unsur kepribadian tertentu seperti sikap, kebiasaan, minat, kebutuhan, motivasi, kecerdasan emosional, penyesuaian diri. Adapun faktor-faktor yang berasal dari luar diri individu atau faktor eksternal yaitu lingkungan keluarga, lingkungan pendidikan, lingkungan masyarakat, dan lingkungan kelompok atau komunitas atau teman.

Berdasarkan pemaparan di atas terdapat banyak faktor yang mempengaruhi prestasi akademik. Selain faktorfaktor tersebut, penelitian ini menemukan bahwa faktor eksternal yang mempengaruhi prestasi akademik pada subjek penelitian yaitu jumlah organisasi di lingkungan kampus yang diikuti dan aktivitas di luar kampus yang berpengaruh terhadap pikiran, tenaga, dan waktu yang dimiliki. Kelelahan dalam menjalani tugas dan tanggungjawab dalam kegiatan organisasi atau aktivitas lain yang diikuti di luar lingkungan kampus serta adanya persoalan pribadi yang dihadapi oleh subjek penelitian dapat menyebabkan kurang maksimalnya mahasiswa aktivis dalam mengerjakan tugas yang diberikan oleh dosen dan kurang maksimal dalam belajar.

3. Hubungan Antara Kecerdasan Emosional Dengan Prestasi Akademik Mahasiswa Aktivis Organisasi Kemahasiswaan Universitas Udayana

Hasil penelitian melalui analisis korelasional Product Moment oleh Karl Pearson menunjukkan bahwa terdapat hubungan atau korelasi antara kecerdasan emosional dan prestasi akademik mahasiswa Universitas Udayana. Hal ini ditunjukkan dari nilai probabilitas pada taraf signifikansi $5 \%$ sebesar 0,021 ( $\mathrm{p}=0,021)$. Artinya adalah nilai probabilitas lebih kecil dari 0,05 ( $\mathrm{p}<0,05)$. Selain itu diperoleh juga nilai koefisien korelasi antara variabel kecerdasan emosional dan prestasi akademik adalah -0,204. Hasil analisis menunjukkan bahwa terdapat tanda negatif pada koefisien korelasi antara kecerdasan emosional terhadap prestasi akademik. Hal tersebut mengartikan bahwa setiap peningkatan pada kecerdasan emosional terjadi penurunan prestasi akademik, begitu juga sebaliknya bahwa peningkatana prestasi akademik berlawanan arah terhadap kecerdasan emosional. Analisis tersebut menyimpulkan bahwa hipotesis alternatif (ha) yang menyatakan ada hubungan positif antara kecerdasan emosional dengan prestasi akademik pada mahasiswa aktivis organisasi kemahasiswaan di lingkungan Universitas Udayana pada penelitian ini tidak diterima atau ditolak.

Hal tersebut menunjukkan bahwa, walaupun individu yang memiliki tingkat kecerdasan emosional yang baik, menjadi lebih terampil dalam menenangkan diri dalam situasi tertekan, mampu mengutamakan yang dianggap lebih prioritas untuk dikerjakan, memiliki motivasi yang baik dalam mencapai sesuatu, lebih baik dalam berhubungan dengan orang lain, mampu memahami orang lain, namun tidak mempengaruhi prestasi akademik secara signifikan dan postif.

Penelitian ini mengkaji hubungan antara kecerdasan emosional dengan prestasi akademik pada mahasiswa aktivis organisasi kemahasiswaan di lingkungan Universitas Udayana. Kesimpulan dari hasil penelitian ini berdasarkan hasil analisis dan pembahasan adalah sebagai berikut:

1. Terdapat hubungan atau korelasi negatif antara kecerdasan emosional dan prestasi akademik mahasiswa Universitas Udayana. Nilai koefisien korelasi antara variabel kecerdasan emosional dan prestasi akademik sebesar -0,204. Hasil analisis tersebut menyimpulkan bahwa hipotesis alternatif (ha) yang menyatakan ada hubungan positif antara kecerdasan emosional dengan prestasi akademik pada mahasiswa aktivis organisasi kemahasiswaan Universitas Udayana pada penelitian ini tidak diterima atau ditolak.

2. Mayoritas mahasiswa aktivis organisasi kemahasiswaan Universitas Udayana memiliki kecerdasan emosional pada kategori tinggi. Hal tersebut ditunjukkan dengan adanya sebanyak 68 orang subjek penelitian $(52.71 \%)$ berada pada skor kecerdasan emosional 78-104.

3. Hasil analisis dari penelitian ini menunjukkan bahwa mayoritas prestasi akademik pada mahasiswa aktivis organisasi kemahasiswaan Universitas Udayana berada pada kategori sedang. Hal tersebut ditunjukkan dengan adanya sebanyak 96 orang dari 129 orang subjek penelitian $(74,42 \%)$ berada pada kategori skor 40-60.

4. Analisis data tambahan atau data demografi yang ditunjukkan dalam penelitian ini yaitu adanya pengaruh keaktifan mengikuti banyaknya jumlah organisasi di lingkungan kampus maupun pengaruh jumlah aktivitas yang 
diikuti di luar lingkungan kampus terhadap prestasi akademik. Hasil analisis menunjukkan bahwa mahasiswa yang mengikuti 1 organisasi di lingkungan kampus dan tidak mengikuti aktivitas organisasi di luar lingkungan kampus, lebih banyak memperoleh prestasi akademik dengan predikat sangat memuaskan dan dengan pujian dibandingkan mahasiswa yang mengikuti 2, 3, 4, dan 5 organisasi yang diikuti di lingkungan kampus maupun di luar lingkungan kampus.

\section{DAFTAR PUSTAKA}

Ahmadi, A. dan Supriyono, W. (2004). Psikologi Belajar. Jakarta: Rineka Cipta.

Ahmaini, D. (2010). Perbedaan Prokrastinasi Akademik Antara Mahasiswa Yang Aktif Dengan Yang Tidak Aktif Dalam Organisasi Kemahasiswaan Pema Universitas Sumatera Utara, Skripsi (tidak dipublikasikan). Medan: Fakultas Psikologi, Universitas Sumatera Utara.

Azwar, S. (2004). Pengantar Psikologi Intelegensi. Yogyakarta: Pustaka Pelajar.

Direktorat Jenderal Pendidikan Tinggi Kementrian Pendidikan dan Kebudayaan Republik Indonesia. (2014). Statistik Perguruan Tinggi di Indonesia. Retrieved Desember, 10, 2014 from: http://dikti.kemdikbud.go.id/

Djojodibroto, R. D. (2004). Tradisi kehidupan akademik. Jakarta: Galangpress Group.

Goleman, D. (2002). Kecerdasan Emosional. Jakarta : PT. Gramedia Pustaka Utama.

(2002). Working With Emotional Intelligence (terjemahan). Jakarta: PT. Gramedia Pustaka Utama.

(2009). Emotional Intelligence: Mengapa EI lebih penting daripada IQ. Jakarta: PT. Gramedia Pustaka Utama.

Gottman, J., \& DeClaire, J. (1998). Kiat-Kiat Membesarkan Anak yang Memilki Kecerdasan Emosional. Jakarta : PT Gramedia Pustaka Utama.

Hadi, S. (2002). Metodologi Research, Yogyakarta: Andi Offset.

Kartono. K. (1990).Pengantar Metodologi Riset Sosial.Bandung: Mandar Maju.

Koesma, R.E. (2003). Prestasi Belajar Di Perguruan Tinggi Di Tinjau Dari Faktor-Faktor Di Dalam Dan Luar Diri Mahasiswa. http://pustaka.unpad.ac.id/wpcontent/uploads/2009/04/prestasi_belajar_di_per guruan_tinggi.pdf

Lubis, C.P. (2004). Implementasi Tri Dharma Perguruan Tinggi dalam Mendukung Disiplin Nasional. eUSU Repository Universitas Sumatera Utara. Retrieved Mei, 15, 2014 from: http://repository.usu.ac.id.

Mansyur, M. (1978). Aktivis Kampus. Jakarta: Cypress Statuta Universitas Udayana. (2009). Bali: Universitas Udayana.

Mulyanafi, F. (2014). Perbedaan Keterampilan Komunikasi Interpersonal Pada Mahasiswa Fisip Universitas
Brawijaya Ditinjau Dari Keaktifan Berorganisasi. Skripsi (tidak dipublikasikan). Malang: Program Studi Psikologi, Universitas Brawijaya.

Parera, F.M. (2000). Pribadi-Pribadi Pembuka Cakrawala. Cendekiawan kampus dan Peneliti Lapangan.

Purwanto. (2010). Metodologi Penelitian Kuantitatif untuk Psikologi Pendidikan, Cetakan Kedua. Yogyakarta: Pustaka Pelajar.

Rachmawati, A. (2013). Kecerdasan Emosi Pada Siswa Yang Bermasalah Di Sekolah. Fakultas Psikologi, Universitas Muhammadiyah Malang. Jurnal Online Psikologi. Vol. 01. No. 02. Thn. 2013. Retrieved Agustus, 28, 2014, from http://ejournal.umm.ac.id

Rustika, I.M. (2014).Faktor-Faktor Yang Mempengaruhi Prestasi Akademik pada Remaja. Disertasi (tidak dipublikasikan).Yogyakarta: Program Doktor Psikologi Fakultas Psikologi Universitas Gadjah Mada.

Santoso, (2005).Metodologi Penelitian Kuantitatf dan Kualitatif.Jakarta: Prestasi Pustaka.

Setyono, A. (2013). Pengaruh Kektifan Berorganisasi dan Kerjainan Beribadah terhadap Kematangan Kepribadian pada Mahasiswa PAI Semester VI Sekolah Tinggi Agama Islam Negeri (STAIN) Salatiga. Skripsi. Retrieved Juni, 28, 2014 from: https://www.google.co.id/url?sa=t\&rct=j\&q=\&es $\mathrm{rc}=\mathrm{s} \&$ source $=$ web $\& \mathrm{~cd}=2 \& \mathrm{cad}=\mathrm{rja} \&$ uact $=8 \& \mathrm{ved}$ $=0 \mathrm{CCgQFj} \mathrm{AB} \&$ url $=\mathrm{http} \% 3 \mathrm{~A} \% 2 \mathrm{~F} \% 2 \mathrm{Feprints} . \mathrm{sta}$ insalatiga.ac.id $\% 2 \mathrm{~F} 227 \% 2 \mathrm{~F} 1 \% 2 \mathrm{FPENGARUH}$ $\%$ 2520KEAKTIFAN\%2520BERORGANISASI $\% 2520$ DAN\%2520KERAJINAN\%2520BERIB ADAH\%2520TERHADAP\%2520KEMATA NGAN\%2520KEPRIBADIAN\%2520$\% 2520$ STAIN\%2520SALATIGA.pdf\&ei=3DvQ U4alBYiyuASCoYC4Dw\&usg=AFQjCNEE_Ih YXpItwyDNnZux7cBsLeiFNQ\&sig2=43tsPi2M OKCSnjYaFVj0Yg

Shapiro, L.E. (2003). Mengajarkan Emotional Intellegence Pada Anak. Jakarta: Gramedia Pustaka Utama.

Smith, P. G. (1983). Quantitative Plant Ecology.Oxford: Blackwell Scientific.

Sobur, A. (2006). Psikologi Umum. Bandung: Pustaka Setia.

Sudarman, P. (2004). Belajar Efektif di Perguruan Tinggi. Bandung: Simbiosa Rekatama Media.

Suryabrata, S. (2006). Psikologi Pendidikan. Jakarta: PT. Raja Grafindo Perkasa.

Undang-Undang Republik Indonesia Nomor 12 Tahun 2012 Tentang Pendidikan Tinggi. 